\title{
EFFECT OF THE STOCKING RATE AND LAND SLOPE ON NITROGEN LOSSES TO WATER ON A GRAZED PASTURE OF SOUTHERN CHILE
}

\author{
F. Salazar ${ }^{1}$, M. Alfaro ${ }^{1}$, S. Ledgard ${ }^{2}$, S. Iraira ${ }^{1}$, N. Teuber ${ }^{1}$, and L. Ramírez ${ }^{1}$ \\ ${ }^{1}$ INIA Remehue, P. O. Box 24-O, Osorno, Chile. ${ }^{2}$ AgResearch, Ruakura Research Centre, Private \\ Bag, 3123 Hamilton, New Zealand Phone: +64-7-8385133. Fax: +64-7-8385155. \\ *Corresponding author: malfaro@inia.cl
}

\begin{abstract}
Most of the studies on nitrogen $(\mathrm{N})$ leaching have been carried out on cut grass, and there is a lack of information on beef grazed grasslands. The objective of this study was to quantify $\mathrm{N}$ runoff and leaching losses in beef production systems with two different immediate stocking rates (63 and 191 Holstein Friesian steers ha $^{-1}$ day $^{-1}$ ) and two land slopes (4 and 12\%). Runoff and leachate samples were analyzed from 2004 to 2006 for total $\mathrm{N}$, nitrate and ammonium. No significant differences for the total $\mathrm{N}$ losses were found between treatments $(p>0.05)$, which were low ranging from 0.9 to $26.8 \mathrm{~kg} \mathrm{~N}$ $\mathrm{ha}^{-1} \mathrm{yr}^{-1}$. The main pathway for the losses was leaching, which contributed $>99 \%$ of the total $\mathrm{N}$ lost. The main form of $\mathrm{N}$ leaching was nitrate- $\mathrm{N}(>84 \%)$. Nitrate-N concentration in runoff samples was high, averaging 14 to $31 \mathrm{mg} \mathrm{L}^{-1}$. We suggest that these low $\mathrm{N}$ losses could be related the low $\mathrm{N}$ fertiliser inputs in the pasture and to the $\mathrm{N}$ adsorption properties of volcanic soils and, so that further research is required on this subject.
\end{abstract}

Keywords: grazing, beef production, nitrogen leaching, runoff, volcanic soils.

\section{INTRODUCTION}

Cattle production is an important economic activity in southern Chile $\left(39^{\circ}\right.$ to $44^{\circ} \mathrm{S} ; 71^{\circ}$ to $73^{\circ} \mathrm{W}$ ), which is based principally on natural and improved pastures. Most of the cattle herd is concentrated in this area, which produces $70 \%$ of the country's milk and $50 \%$ of its meat (ODEPA, 2006, 2007; Anrique, 1999). In recent years, cattle production has intensified, through increasing stocking rates (from $0.42 \mathrm{AU} \mathrm{ha}^{-1}$ up to 1 or more $\mathrm{AU} \mathrm{ha}^{-1}$ ) (Smith et al., 2002) and use of purchased fertilisers and concentrates. Nowadays, Chile is an exporting country for milk and meat production, which is expected to increase in the future.

Globally, there is an increasing concern about the impact of farm intensification on the environment, which in European countries has resulted in specific legislation, as well as guidelines for good agricultural practices (EC, 1991; Ignazi, 1996; Archer and Marks, 1997; Neeteson, 2000).

Farming is recognised as a major source of nitrate $\left(\mathrm{NO}_{3}{ }^{-}\right)$in ground and surface waters worldwide (e.g. European Environment Agency, 1995; Powlson, 2000). It has been estimated that 
agriculture contributes between 37 and $82 \%$ of the nitrogen $(\mathrm{N})$ input into surface waters of Western Europe (waters of Western Europe (Isermann, 1990). Within agriculture, cattle production systems are considered one of the most important contributors due to their low efficiency of $\mathrm{N}$ use (Isermann, 1990).

In cattle production systems one of the most important pathways of $\mathrm{N}$ losses is leaching (e.g. Alfaro et al., 2008), with leaching losses being greater from grazed pasture than from a cut sward, and likely to equal or exceed the range observed in arable production systems (Ryden et al., 1984)

In New Zealand on grazed pastures with milking cows and no $\mathrm{N}$ fertiliser application, Ledgard et al. (1999) showed $\mathrm{N}$ losses ranging from 20 up to $74 \mathrm{~kg} \mathrm{~N}$ $\mathrm{ha}^{-1} \mathrm{yr}^{-1}$. Betteridge et al. (2004) measured $\mathrm{N}$ leaching from pasture grazed by beef cattle at 12 to $17 \mathrm{~kg} \mathrm{NO}_{3}^{-}-\mathrm{N} \mathrm{ha}^{-1} \mathrm{yr}^{-1}$. In Chile most studies have been done on cut grass, using lysimeters (Nissen and Daroch, 1991; Salazar, 2002) with only few studies published evaluating $\mathrm{N}$ losses due to leaching and/or runoff (Alfaro et al., 2005; Alfaro et al., 2008; Núñez et al., 2010). The latter study reported $\mathrm{N}$ losses of 33 and $59 \mathrm{~kg} \mathrm{~N} \mathrm{ha}^{-1} \mathrm{yr}^{-1}$. The objective of this study was to quantify $\mathrm{N}$ losses in runoff and leaching in beef production systems with two immediate stocking rates and two land slopes on a volcanic soil.

\section{MATERIALS AND METHODS}

The experiment was carried out between 2004 and 2006 at the National Institute for Agricultural Research (INIA), Remehue Research Centre (4035'S, $\left.73^{\circ} 12^{\prime} \mathrm{W}\right)$. The soil is an Andisol of the Osorno soil series (Typic Hapludands;
CIREN, 2003), which at the experimental site has more than $1 \mathrm{~m}$ depth, loamy texture within the $0-60 \mathrm{~cm}$ layers, high organic matter $\left(170 \mathrm{~g} \mathrm{~kg}^{-1}\right)$ and available phosphorus (Olsen $\mathrm{P}, 25 \mathrm{mg} \mathrm{kg}^{-1}$ ) concentrations, and low aluminum saturation index. According to the meteorological station at the site, the 30 years average rainfall for the area is 1,260

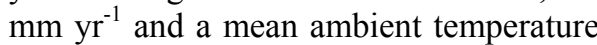
of $11.3^{\circ} \mathrm{C}\left(7.2\right.$ to $\left.15.6^{\circ} \mathrm{C}\right)$.

In this study, animals were managed under rotational grazing in closed systems ( 2 ha each) on a permanent pasture 25 years old that had been always used for grazing with beef cattle. The grass area was divided in 54 equal grazing strips, offering three grazing strips $\left(1254 \mathrm{~m}^{2}\right)$ every 3 days or one grazing strip $\left(418 \mathrm{~m}^{2}\right)$ per day, which was equivalent to two different immediate stocking rates (number of animals per area unit per day) of 63 steers and 191 steers ha ${ }^{-1}$ day $^{-1}$, respectively. These treatments were evaluated on a $4 \%$ slope field and the 63 steers $\mathrm{ha}^{-1}$ day $^{-1}$ treatment was also evaluated in a $12 \%$ slope field. Grazing was carried out with Holstein-Friesian steers with initial live weights of $212 \pm$ $9.9 \mathrm{~kg}, 173 \pm 23.0 \mathrm{~kg}$ and $248 \pm 12.0 \mathrm{~kg}$ for 2004, 2005 and 2006, respectively so that the average stocking rate at the beginning of each experimental season was 1.3 AU ha ${ }^{-1}$. Treatments were fertilized each year in autumn with $45 \mathrm{~kg}$ $\mathrm{N}$ ha ${ }^{-1}$ (urea, $46 \% \mathrm{~N}, 1^{\text {st }}$ year; $2^{\text {nd }}$ and $3^{\text {rd }}$ year , sodium nitrate, $16 \% \mathrm{~N}$ ) and in the spring with $25 \mathrm{~kg} \mathrm{~N}^{-1}$ (sodium nitrate) and $29 \mathrm{~kg} \mathrm{P}^{-1}$ (triple superphosfate, $46 \% \quad \mathrm{P}_{2} \mathrm{O}_{5}$ ). Detailed information on systems description and management can be found in Alfaro et al. (2009).

To quantify $\mathrm{N}$ losses in surface runoff, three surface lysimeters $(5 \times 5 \mathrm{~m})$ were established in each treatment, according to the methodology described by Alfaro and Salazar (2007), and surface 
runoff was collected three times per week. The accumulated surface runoff was measured at each sampling date. Leaching losses at $60 \mathrm{~cm}$ depth were estimated using ceramic cups (Webster et al., 1993), with three cups per surface lysimeter $(n=9$ per treatment). Samples were collected fortnightly in the first year and after each $100 \mathrm{~mm}$ of drainage in the $2^{\text {nd }}$ and $3^{\text {rd }}$ year. Drainage for the period was calculated as the difference between rainfall and evapotranspiration for each sampling period, according to Lord and Shepherd (1993). Total rainfall and evapotranspiration for the period was registered with an automatic weather station placed at the experimental site (1 $\mathrm{km}$ distance). Leachate samples were frozen until analysis for available $\mathrm{N}\left(\mathrm{NO}_{3}{ }^{-}\right.$ and $\mathrm{NH}_{4}{ }^{+}$). Runoff samples were stored at $4^{\circ} \mathrm{C}$ until analysis for available N. Nitrate was measured using the salicylic acid method (Robarge et al, 1983), and ammonium was determined through the indophenol methodology (Mulvaney, 1996) using and authomated sample analyser (Skalar SA 1050). The limit of determination for $\mathrm{NO}_{3}^{-}$and $\mathrm{NH}_{4}^{+}$ determination was 0.2 and $0.1 \mathrm{mg} \mathrm{L}^{-1}$, respectively. On runoff samples, total $\mathrm{N}$ was determined using the Ntube test method 10071 (®Hach, 2000) and the dissolved organic $\mathrm{N}$ (DON) was estimated as the difference between total $\mathrm{N}$ and available $\mathrm{N}$ in the samples.

Total $\mathrm{N}$ losses were calculated as the product of drainage and $\mathrm{N}$ concentration in the respective samples. Total $\mathrm{N}$ losses for the experimental period were calculated as the sum of $\mathrm{N}$ losses in runoff and $\mathrm{N}$ leaching losses.

Analysis of variance (ANOVA) was used to compare nitrate and ammonium concentrations, surface runoff losses, leaching losses and overall $\mathrm{N}$ losses between the treatments tested. Genstat 7.1 was used as the statistical package.

\section{RESULTS AND DISCUSSION}

\section{Rainfall, evaporation and drainage}

Rainfall, evaporation and drainage data from April to December for 2004, 2005 and 2006, and a 30 year average for the INIA-Remehue meteorological station are presented in Figure 1. For this period of evaluation, the year 2004 had a similar rainfall to the 30 year average, however, 2005 and 2006 had a higher rainfall, being 195.6 and $176.0 \mathrm{~mm}$ higher than the 30 year average. Evaporation was similar for 2005 and 2006 compared to the 30 year average, but in 2004 was lower than the average $(-47.2 \mathrm{~mm})$. According to this information, estimated drainage for 2005 and 2006 were 306.7 and $220.9 \mathrm{~mm}$ higher than for 2004. The high drainage observed in the second and third experimental seasons had an impact on $\mathrm{N}$ leaching losses, because this parameter, with $\mathrm{N}$ concentration, determines $\mathrm{N}$ losses.

Results also showed that the main pathway of water movement was leaching through the soil, accounting for $99 \%$ of the total volume of drainage water collected $(p<0.05)$, and that the immediate stocking rate and slope tested did not affect the proportion of water loss due to leaching or runoff ( $p>$ 0.05). This data are in agreement with Alfaro et al. $(2005,2009)$ for a study carried out in the same area with beef cattle $(6 \%$ field slope $)$ and with Ledgard et al. (1999) for grazing cow systems on a similar soil type in New Zealand.

High water runoff volumes were collected in wet years, and were important in critical periods such as the start of autumn when the soil was dry after summer or during winter with waterlogged conditions. The impact of water runoff on $\mathrm{N}$ losses to water would 


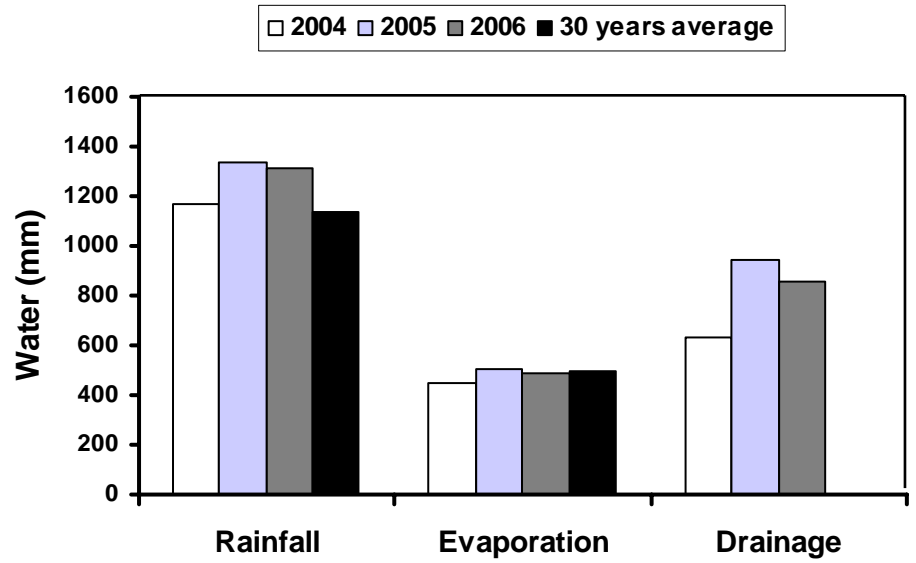

Figure 1. Rainfall, evaporation and drainage from April to December for 2004, 2005 and 2006, compared with the 30 year average. INIA-Remehue meteorological station.

be more important when autumn or spring fertilization of grass matches high rainfall periods, such as those observed in spring time during 2005 and 2006.

\section{Nitrogen runoff losses}

The field slope affected either organic $\mathrm{N}$, ammonium $\mathrm{N}$ or nitrate $\mathrm{N}$ concentration with high values observed in each year for the $12 \%$ slope compared to $4 \%$ slope treatments (Table $1 ; p \leq 0.05$ ). On the other hand, grazing intensity affected nitrate concentrations only during year 1 , which increased (Table $1 ; p \leq 0.05$ ). There was no interaction between the stocking rate and the field slope for $\mathrm{N}$ losses in runoff $(p>0.05)$.

There were differences between years for $\mathrm{N}$ losses due to runoff, following the order $2006>2005>2004(p<0.01)$, which was associated to differences in rainfall between years. During the three years, nitrate-N concentration in runoff exceeded the Chilean and EC limit for drinking water (11.3 $\mathrm{mg} \mathrm{L}^{-1}$; EC, 1991).

In addition, ammonium concentrations also were higher than the values established in the Chilean normative for surface water (1 $\mathrm{mg} \mathrm{L}^{-1}$, DS 87/01). High $\mathrm{N}$ losses were observed during winter and after spring fertilizer applications, especially in rainfall periods, so that $\mathrm{N}$ transport in runoff from grazing areas could be important in paddocks located next to surface waters, affecting the use of water for other activities such as aquaculture and tourism (Alfaro et al., 2005). Good agriculture practices could be used to reduce the risk of water pollution due to $\mathrm{N}$ runoff. Buffer strips have been shown to be effective in protecting surface waters (e.g. Hickey and Doran, 2004). In addition, it is important to match $\mathrm{N}$ fertilization rates with $\mathrm{N}$ requirements by grass to avoid surpluses as these systems tend to accumulate $\mathrm{N}$, as soil and gate budgets have shown (Alfaro et al., 2009).

Average data for the three years of this study showed that only the field slope affected total $\mathrm{N}$ losses due to runoff ( $p \leq$ 0.05 ). This would be related to both the direct transport of dissolved nitrate in the runoff water and the effect of soil particle transport which resulted in high DON 
Table 1. Average nitrogen concentration in surface runoff samples $\left(\mathrm{mg} \mathrm{L}^{-1}\right)$ and total losses in surface runoff $\left(\mathrm{kg} \mathrm{N} \mathrm{ha}^{-1}\right)$ for treatments with different stocking rates and field slopes, 2004-2006 ( \pm sem).

\begin{tabular}{|c|c|c|c|}
\hline Treatment & $\begin{array}{c}63 \text { steers ha }{ }^{-1} \mathrm{~d}^{-1} \\
4 \% \text { slope }\end{array}$ & $\begin{array}{c}191 \text { steers ha } \\
4 \% \text { slope }\end{array}$ & $\begin{array}{l}63 \text { steers ha }{ }^{-1} d^{-1} \text {, } \\
12 \% \text { slope }\end{array}$ \\
\hline \multicolumn{4}{|l|}{2004} \\
\hline \multicolumn{4}{|c|}{ Average surface runoff concentrations and range $\left(\mathrm{mg} \mathrm{L}^{-1}\right)$} \\
\hline $\mathrm{N}-\mathrm{NH}_{4}^{+}$ & $27 \pm 11.3 \mathbf{a}$ & $30 \pm 13.9 \mathbf{a}$ & $43 \pm 15.7 \mathbf{a}$ \\
\hline $\mathrm{N}-\mathrm{NO}_{3}^{-}$ & $26 \pm 13.6 \mathbf{b}$ & $61 \pm 23.9 \mathbf{a}$ & $52 \pm 19.9$ a \\
\hline Organic N & $15 \pm 6.1 \mathbf{b}$ & $14 \pm 3.7 \mathbf{b}$ & $77 \pm 9.7 \mathbf{a}$ \\
\hline \multicolumn{4}{|l|}{ Total $\mathrm{N}$ losses $\left(\mathrm{kg} \mathrm{ha}^{-1}\right)$} \\
\hline $\mathrm{N}-\mathrm{NH}_{4}{ }^{+}$in surface runoff & $0.01 \pm 0.001 \mathbf{a}$ & $0.03 \pm 0.003 \mathbf{a}$ & $0.04 \pm 0.005 \mathbf{a}$ \\
\hline $\mathrm{N}-\mathrm{NO}_{3}{ }^{-}$in surface runoff & $0.003 \pm 0,0.0016 \mathbf{a}$ & $0.004 \pm 0.0022 \mathbf{a}$ & $0.006 \pm 0.0047 \mathbf{a}$ \\
\hline Organic $\mathrm{N}$ in surface runoff & $0.007 \pm 0.004 \mathbf{c}$ & $0.03 \pm 0.003 \mathbf{b}$ & $0.17 \pm 0.037 \mathbf{a}$ \\
\hline Total & $0.02 \mathrm{~b}$ & $0.06 \mathrm{~b}$ & $0.22 \mathrm{a}$ \\
\hline \multicolumn{4}{|l|}{2005} \\
\hline \multicolumn{4}{|c|}{ Average surface runoff concentrations and range $\left(\mathrm{mg} \mathrm{L}^{-1}\right)$} \\
\hline $\mathrm{N}-\mathrm{NH}_{4}^{+}$ & $11 \pm 1.2 \mathbf{b}$ & $9 \pm 1.4 \mathbf{b}$ & $25 \pm 3.5 \mathbf{a}$ \\
\hline $\mathrm{N}-\mathrm{NO}_{3}^{-}$ & $17 \pm 3.0 \mathbf{a}$ & $13 \pm 4.5 \mathbf{a}$ & $32 \pm 7.4 \mathbf{a}$ \\
\hline Organic N & $17 \pm 4.09 \mathbf{b}$ & $11 \pm 2.30 \mathbf{b}$ & $38 \pm 5.81 \mathbf{a}$ \\
\hline \multicolumn{4}{|l|}{ Total N losses $\left(\mathrm{kg} \mathrm{ha}^{-1}\right)$} \\
\hline $\mathrm{N}-\mathrm{NH}_{4}{ }^{+}$in surface runoff & $0.04 \pm 0.002 \mathbf{b}$ & $0.06 \pm 0.016 \mathbf{b}$ & $0.09 \pm 0.016 \mathbf{a}$ \\
\hline $\mathrm{N}^{-\mathrm{NO}_{3}}{ }^{-}$in surface runoff & $0.07 \pm 0.007 \mathbf{a}$ & $0.09 \pm 0.021 \mathbf{a}$ & $0.06 \pm 0.012 \mathbf{a}$ \\
\hline Organic $\mathrm{N}$ in surface runoff & $0.07 \pm 0.013 \mathbf{b}$ & $0.14 \pm 0.024 \mathbf{b}$ & $0.26 \pm 0.041 \mathbf{a}$ \\
\hline Total & 0.18 c & $0.29 \mathrm{~b}$ & 0.41 a \\
\hline \multicolumn{4}{|c|}{2006} \\
\hline \multicolumn{4}{|c|}{ Average surface runoff concentrations and range $\left(\mathrm{mg} \mathrm{L}^{-1}\right)$} \\
\hline $\mathrm{N}-\mathrm{NH}_{4}^{+}$ & $20 \pm 2.8 \mathbf{a}$ & $12 \pm 4.7 \mathbf{a}$ & $17 \pm 2.7 \mathbf{a}$ \\
\hline $\mathrm{N}-\mathrm{NO}_{3}^{-}$ & $10 \pm 3.0 \mathbf{a}$ & $27 \pm 8.1 \mathbf{a}$ & $20 \pm 2.9 \mathbf{a}$ \\
\hline Organic N & $22 \pm 3.8 \mathbf{a}$ & $17 \pm 7.4 \mathbf{a}$ & $24 \pm 5.1 \mathbf{a}$ \\
\hline \multicolumn{4}{|l|}{ Total N losses $\left(\mathrm{kg} \mathrm{ha}^{-1}\right)$} \\
\hline $\mathrm{N}-\mathrm{NH}_{4}^{+}$in surface runoff & $0.15 \pm 0.020 \mathbf{a}$ & $0.10 \pm 0.040 \mathbf{a}$ & $0.19 \pm 0.035 \mathbf{a}$ \\
\hline $\mathrm{N}^{-\mathrm{NO}_{3}}{ }^{-}$in surface runoff & $0.08 \pm 0.022 \mathbf{b}$ & $0.27 \pm 0.064 \mathbf{a}$ & $0.23 \pm 0.043 \mathbf{a}$ \\
\hline Organic $\mathrm{N}$ in surface runoff & $0.15 \pm 0.005 \mathbf{b}$ & $0.13 \pm 0.032 \mathbf{b}$ & $0.21 \pm 0.008 \mathbf{a}$ \\
\hline Total & $0.38 \mathrm{c}$ & $0.50 \mathrm{~b}$ & $0.63 \mathrm{a}$ \\
\hline
\end{tabular}

Different letters in columns show significant differences among treatments $(p \leq 0.05)$

\pm sem: standard error of the mean 
Continued ..........

\begin{tabular}{|c|c|c|c|}
\hline Treatment & $\begin{array}{c}63 \text { steers ha }^{-1} \mathrm{~d}^{-1} \text {, } \\
4 \% \text { slope }\end{array}$ & $\begin{array}{c}191 \text { steers ha }^{-1} \mathrm{~d}^{-1} \text {, } \\
4 \% \text { slope }\end{array}$ & $\begin{array}{c}63 \text { steers ha }{ }^{-1} \mathrm{~d}^{-1} \text {, } \\
12 \% \text { slope }\end{array}$ \\
\hline \multicolumn{4}{|l|}{ Average 2004-06 } \\
\hline \multicolumn{4}{|c|}{ Average surface runoff concentrations and range $\left(\mathrm{mg} \mathrm{L}^{-1}\right)$} \\
\hline $\mathrm{N}-\mathrm{NH}_{4}^{+}$ & $20 \pm 3.7 \mathbf{a}$ & $18 \pm 4.1 \mathbf{a}$ & $34 \pm 5.7 \mathbf{a}$ \\
\hline $\mathrm{N}-\mathrm{NO}_{3}^{-}$ & $14 \pm 1.8 \mathrm{c}$ & $23 \pm 4.0 \mathbf{b}$ & $31 \pm 8.7 \mathbf{a}$ \\
\hline Organic N & $18 \pm 2.6 \mathbf{b}$ & $14 \pm 2.6 \mathbf{b}$ & $47 \pm 8.6 \mathbf{a}$ \\
\hline \multicolumn{4}{|l|}{ Total N losses $\left(\mathrm{kg} \mathrm{ha}^{-1}\right)$} \\
\hline $\mathrm{N}-\mathrm{NH}_{4}^{+}$in surface runoff & $0.07 \pm 0.020 \mathbf{b}$ & $0.07 \pm 0.015 \mathbf{b}$ & $0.12 \pm 0.023 \mathbf{a}$ \\
\hline $\mathrm{N}^{-\mathrm{NO}_{3}}{ }^{-}$in surface runoff & $0.06 \pm 0.011 \mathbf{b}$ & $0.14 \pm 0.037 \mathbf{a}$ & $0.11 \pm 0.031 \mathbf{a}$ \\
\hline Organic $\mathrm{N}$ in surface runoff & $0.07 \pm 0.021 \mathbf{b}$ & $0.10 \pm 0.021 \mathbf{b}$ & $0.21 \pm 0.022 \mathbf{a}$ \\
\hline Total & $0.20 \mathrm{~b}$ & $0.31 \mathrm{~b}$ & $0.44 \mathrm{a}$ \\
\hline
\end{tabular}

Different letters in columns show significant differences among treatments $(p \leq 0.05)$

\pm sem: standard error of mean

losses (Jarvis, 2002). Ammonium losses were high in the $12 \%$ slope treatment probably due to direct runoff of urine when the soil was saturated. Studies carried out by Preedy et al. (2001) in UK showed similar results after manure application to grass.

Grazing intensity did not significantly affect DON and ammonium losses, however, higher losses of nitrate were observed in the higher stocking rate treatment $(p \leq 0.05)$, which could be attributed to the higher amount of excreta under the increased stocking rate in agreement with data reported by Haynes and Williams (1993).

\section{Nitrogen leaching losses}

Field slope and grazing intensity did not significantly affect $\mathrm{NO}_{3}-\mathrm{N}$ and $\mathrm{NH}_{4}-\mathrm{N}$ concentration and total $\mathrm{N}$ losses $(p>$ 0.05 ; Table 2). Nitrogen leaching losses were greater in 2005 and 2006 than in 2004 because the drainage was higher for these two years. In addition, $\mathrm{N}$ losses at the end of the drainage period (spring period) represented between $58 \%$ to $82 \%$ of the total losses for 2005 and 2006, so that on rainy springs $\mathrm{N}$ input as fertilizer had an important effect on $\mathrm{N}$ losses, which should be considered in cattle production systems with more $\mathrm{N}$ intensive use, or where soil $\mathrm{N}$ levels are high.

Nitrate-N concentrations were low in the three drainage seasons, being below $10 \mathrm{mg} \mathrm{L}^{-1}$ for all treatments and evaluation years (Figure 2), with higher concentrations observed at the end of the drainage period. These values were below the EC limit for drinking water (EC, 1991). Average concentrations were less than $2.8 \mathrm{mg} \mathrm{L}^{-1}$ and $0.06 \mathrm{mg} \mathrm{L}^{-1}$ for $\mathrm{NO}_{3}$ $\mathrm{N}$ and $\mathrm{NH}_{4}-\mathrm{N}$, respectively (Table 2).

Nitrogen losses occur mainly as $\mathrm{NO}_{3}^{-}$, representing from 84 to $99 \%$ of the total $N$ leached. Similar results have been reported by Ledgard et al. (1999) for a study carried out in New Zealand on volcanic soils. Ammonium nitrogen is easily transformed in the soil to nitrate, which is the main $\mathrm{N}$ form in soils (e.g. Di and Cameron, 2002). However, studies have also showed that $\mathrm{N}$ could be leached as organic form (Hawkins and Scholefield, 2000; Murphy et al., 2000). 
Table 2. Average $\mathrm{N}$ concentration in leachates $\left(\mathrm{mg} \mathrm{L}^{-1}\right)$ and total $\mathrm{N}$ leaching losses $(\mathrm{kg}$ $\mathrm{N} \mathrm{ha}^{-1}$ ) for treatments with different immediate stocking rates and field slopes, 20042006 ( \pm sem).

\begin{tabular}{|c|c|c|c|c|}
\hline Treatment & & $\begin{array}{c}63 \text { steers ha }{ }^{-1} d^{-1} \text {, } \\
4 \% \text { slope }\end{array}$ & $\begin{array}{c}191 \text { steers ha } \\
4 \% \text { slope }\end{array}$ & $\begin{array}{c}63 \text { steers ha }^{-1} \mathrm{~d}^{-1} \text {, } \\
12 \% \text { slope }\end{array}$ \\
\hline \multicolumn{5}{|c|}{ Average leachate concentrations and range $\left(\mathrm{mg} \mathrm{L}^{-1}\right)$} \\
\hline \multirow[t]{3}{*}{$\mathrm{N}-\mathrm{NH}_{4}^{+}$} & 2004 & $0.03 \pm 0.006 \mathbf{a}$ & $0.04 \pm 0.006 \mathbf{a}$ & $0.04 \pm 0.001 \mathbf{a}$ \\
\hline & 2005 & $0.01 \pm 0.006 \mathbf{a}$ & $0.02 \pm 0.016 \mathbf{a}$ & $0.02 \pm 0.014 \mathbf{a}$ \\
\hline & 2006 & $0.13 \pm 0.062 \mathbf{a}$ & $0.02 \pm 0.006 \mathbf{a}$ & $0.01 \pm 0.004 \mathbf{a}$ \\
\hline \multirow[t]{3}{*}{$\mathrm{N}-\mathrm{NO}_{3}^{-}$} & 2004 & $0.3 \pm 0.10 \mathbf{a}$ & $0.9 \pm 0.32 \mathbf{a}$ & $0.1 \pm 0.02 \mathbf{a}$ \\
\hline & 2005 & $1.7 \pm 1.04 \mathbf{a}$ & $2.8 \pm 0.51 \mathbf{a}$ & $0.2 \pm 0.09 \mathbf{a}$ \\
\hline & 2006 & $2.3 \pm 0.34 \mathbf{a}$ & $2.2 \pm 1.85 \mathbf{a}$ & $2.5 \pm 1.21 \mathbf{a}$ \\
\hline \multicolumn{5}{|l|}{ Total $\mathrm{N}$ losses $\left(\mathrm{kg} \mathrm{ha}^{-1}\right)$} \\
\hline \multirow[t]{4}{*}{${\mathrm{N}-\mathrm{NH}_{4}}^{+}$in leachates } & 2004 & $0.2 \pm 0.04 \mathbf{a}$ & $0.2 \pm 0.04 \mathbf{a}$ & $0.2 \pm 0.01 \mathbf{a}$ \\
\hline & 2005 & $0.1 \pm 0.05 \mathbf{a}$ & $0.2 \pm 0.15 \mathbf{a}$ & $0.2 \pm 0.13 \mathbf{a}$ \\
\hline & 2006 & $1.1 \pm 0.53 \mathbf{a}$ & $0.2 \pm 0.05 \mathbf{a}$ & $0.1 \pm 0.04 \mathbf{a}$ \\
\hline & Average & $0.5 \pm 0.21 \mathbf{a}$ & $0.2 \pm 0.06 \mathbf{a}$ & $0.2 \pm 0.05 \mathbf{a}$ \\
\hline \multirow[t]{4}{*}{$\mathrm{N}^{-\mathrm{NO}_{3}}{ }_{3}^{-}$in leachates } & 2004 & $2.0 \pm 0.64 \mathbf{a}$ & $5.4 \pm 2.00 \mathbf{a}$ & $0.9 \pm 0.14 \mathbf{a}$ \\
\hline & 2005 & $16.3 \pm 9.82 \mathbf{a}$ & $26.8 \pm 4.83 \mathbf{a}$ & $1.5 \pm 0.83 \mathbf{a}$ \\
\hline & 2006 & $19.8 \pm 2.88 \mathbf{a}$ & $18.8 \pm 15.79 \mathbf{a}$ & $21.5 \pm 10.38 \mathbf{a}$ \\
\hline & Average & $12.7 \pm 4.02 \mathbf{a}$ & $17.0 \pm 5.64 \mathbf{a}$ & $8.0 \pm 3.59 \mathbf{a}$ \\
\hline \multicolumn{5}{|l|}{ Total $\left(\mathrm{kg} \mathrm{N} \mathrm{ha}^{-1}\right)$} \\
\hline & 2004 & $2.2 \pm 0.61 \mathbf{a}$ & $5.7 \pm 1.96 \mathbf{a}$ & $1.1 \pm 0.15 \mathbf{a}$ \\
\hline & 2005 & $16.4 \pm 9.81 \mathbf{a}$ & $27.0 \pm 4.85 \mathbf{a}$ & $1.7 \pm 0.81 \mathbf{a}$ \\
\hline & 2006 & $20.9 \pm 3.16 \mathbf{a}$ & $18.9 \pm 15.80 \mathbf{a}$ & $21.6 \pm 10.39 \mathbf{a}$ \\
\hline & Average & $13.2 \pm 3.95 \mathbf{a}$ & $17.2 \pm 5.69 \mathbf{a}$ & $8.1 \pm 3.55 \mathbf{a}$ \\
\hline
\end{tabular}

Different letters in columns show significant differences among treatments $(p \leq 0.05)$ \pm sem: standard error of mean

Measurements in this study indicate some organic $\mathrm{N}$ leaching losses, however, there was a high variability between samples, and data are not presented in this paper.

Cumulative annual $\mathrm{N}$ losses due to inorganic $\mathrm{N}$ leaching were small and ranged from $c$. 0.9 to $26.8 \mathrm{~kg} \mathrm{ha}^{-1} \mathrm{yr}^{-1}$. No significant differences were observed between treatments $(p>0.05$; Table 2$)$. There was a high variability among the leaching samples within treatments and years. This situation is common when $\mathrm{N}$ is evaluated in soil and especially on grazing systems due to patches of urine and faeces in the pasture (Haynes and Williams, 1993).

Nitrogen leaching values determined in the present study were higher than those reported by Nissen and Daroch. (1991), Misselbrook et al. (1996), Salazar (2002) and Salazar et al. (2005) for cut grass, and lower than values reported by 

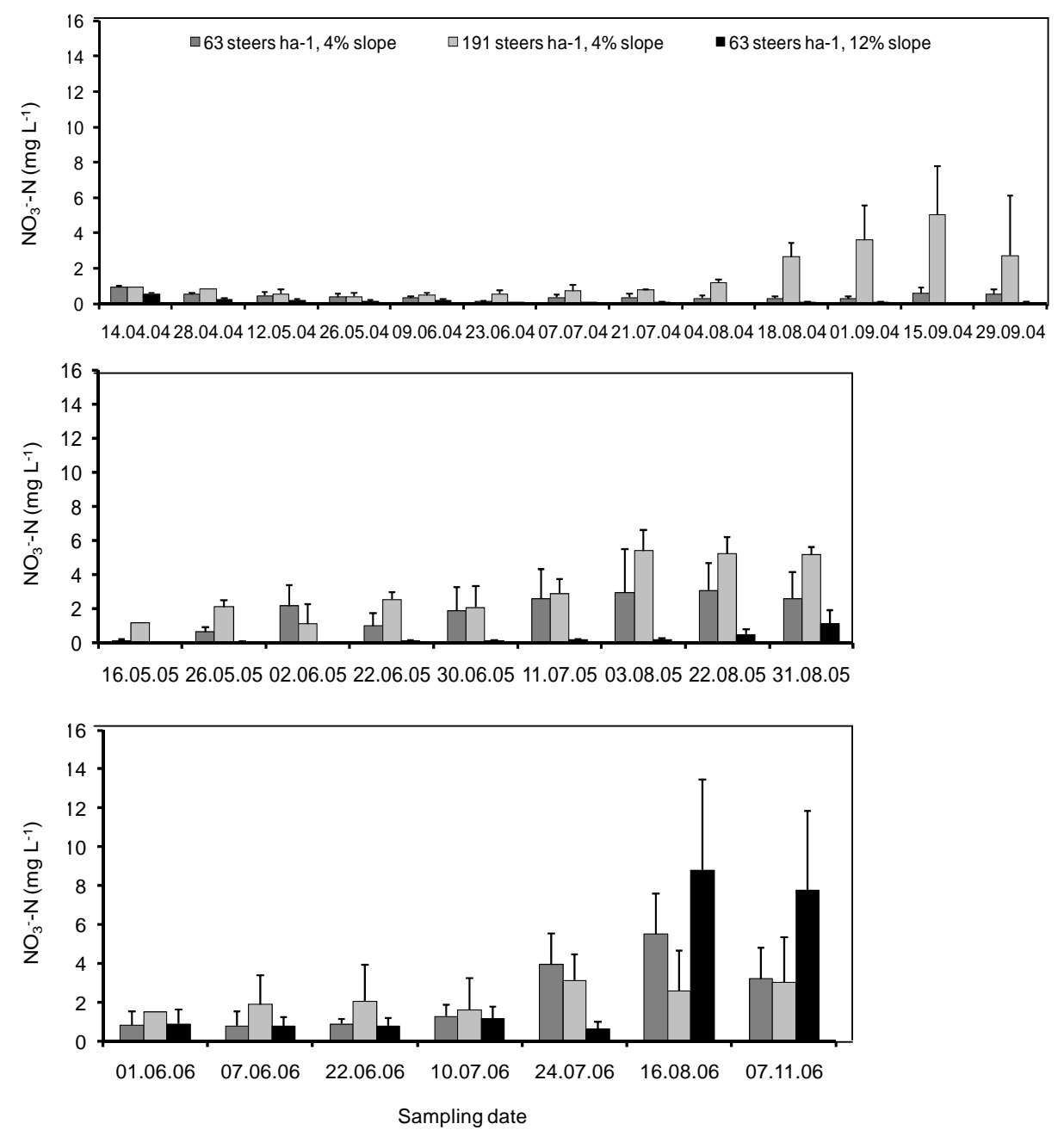

Figure 2. Concentration of $\mathrm{NO}_{3}{ }^{-}-\mathrm{N}$ in leachate samples for the different treatments and sampling dates in 2004, 2005 and 2006.

de Klein and Ledgard (2001), Cameron et al. (1992) and Cameron and $\mathrm{Di}$ (2004) for grazed pastures in New Zealand. Many studies have shown that $\mathrm{N}$ leaching losses are higher in crops and in grazed pastures compared to cut grasslands. An evaluation carried out by Ryden et al. (1984) showed 5.6 times higher losses in a grazed pasture compared to a similar pasture under cutting. Higher $\mathrm{N}$ losses due to leaching from grazed grassland compared to cut grassland could be explained by the high concentration of $\mathrm{N}(600-1,000 \mathrm{~kg} \mathrm{~N}$ $\mathrm{ha}^{-1}$ ) under urine or faeces patches (Haynes and Williams, 1993), which are well above the needs of the plants and so prone to leaching losses.

The low $\mathrm{N}$ leaching values determined in the present study compared with published data elsewhere on grazed 
pastures, could be associated to differences in soil type, animal type and intensification of the cattle production system evaluated, especially on $\mathrm{N}$ use. Most of the published studies abroad have been carried out using dairy cows, with high stocking rates (e.g. 2.5 cows ha $^{-1}$; de Klein and Ledgard, 2001). In addition, $\mathrm{N}$ fertilizer rates in these experiments are higher than the one used in the present study, which has an important effect on $\mathrm{N}$ losses (Ledgard et al., 1996).

Recent studies have shown that forest volcanic soil of Southern Chile have very specialised microbial and abiotic retention processes which can reduce the risk for $\mathrm{N}$ leaching, despite the high $\mathrm{N}$ turnover rates determined in this soil (Huygens et al., 2008). Studies in these ecosystems indicated very high gross $\mathrm{NH}_{4}^{+}$ production fluxes, but also a suppression of autotrophic nitrification as a result of strong competition for available $\mathrm{NH}_{4}{ }^{+}$by abiotic immobilization processes and $\mathrm{NH}_{4}^{+}$assimilating heterotrophic microorganisms (Huygens et al. 2007). More studies are required to understand the role of these processes on $\mathrm{N}$ dynamics in grazed soils of southern Chile.

Results from the present study suggest that livestock production systems in southern Chile could be intensified through the use of increasing stocking rates and fertilizers inputs, but the matching between agronomic managements and intensive rainfall should be considered as a strong constraint for $\mathrm{N}$ losses to the wider environment. In addition, other pathways of $\mathrm{N}$ losses should be considered, such as losses as ammonia and nitrous oxide emissions, for future studies. Both pathways could be relevant for both $\mathrm{N}$ use efficiency and greenhouse generation and global warming.

gasses

\section{CONCLUSIONS}

Results from this study showed that field slope and immediate stocking rate did not affect total $\mathrm{N}$ leaching losses significantly $(p>0.05)$. However, these factors affect $\mathrm{N}$ concentration in runoff water, where higher values were observed in $12 \%$ slope and 191 steers ha $^{-1}$ compared with $4 \%$ slope and 63 steers ha $^{-1}$. Nitrogen losses due to runoff were low $\left(<0.65 \mathrm{~g} \mathrm{ha}^{-1} \mathrm{yr}^{-1}\right)$, however, in some sampling periods high concentrations were observed which overpass the EC concentration limit for drinking water. In the $4 \%$ slope treatment runoff losses were as nitrate, DON and ammonium and in the $12 \%$ slope treatment $\mathrm{N}$ was mainly transferred as dissolved organic N. Nitrogen was mainly lost by leaching, nor by runoff ( $>99 \%$ of total $\mathrm{N}$ losses), so that losses in this pathway ranged from 0.9 to $26.8 \mathrm{~kg} \mathrm{ha}^{-1}$ $\mathrm{yr}^{-1}$, where nitrate accounted for $>84 \%$ of the $\mathrm{N}$ losses. Nitrate- $\mathrm{N}$ concentrations in leachates were low, with annual averages lower than $2.8 \mathrm{mg} \mathrm{L}^{-1}$. There was a year effect on $\mathrm{N}$ losses due to leaching, which can be explained for higher drainage in 2005 and 2006 compared to 2004. Late rainfall in late winter and spring had an important impact on $\mathrm{N}$ losses, representing from $58 \%$ to $82 \%$ of the total $\mathrm{N}$ losses. We suggest that low leaching losses reported in this study could be related to the low $\mathrm{N}$ fertiliser inputs and the potential role of $\mathrm{N}$ adsorption in the volcanic soils. Further research is required to determine the contribution of this process to $\mathrm{N}$ cycling in grassland soils of southern Chile. 


\section{ACKNOWLEDGMENTS}

This research was funded by the Scientific and Technological Research Council (FONDECYT), grants 1040104 and 7040030 .

\section{REFERENCES}

Alfaro, M., Salazar, F., Iraira, S., Teuber, N., Ramírez, L. 2005. Nitrogen runoff and leaching losses under two different stocking rates on beef production systems of southern Chile. Gayana Bot. 62, 130-138.

Alfaro, M., Salazar, F. 2007. Phosphorus lossses in surface run-off from grazed permanent pasture on a volcanic soil from Chile. Soil Use Manage. $23,323-327$.

Alfaro, M., Salazar, F., Iraira, S., Teuber, N., Ramírez, L. 2008. Dynamics of nitrogen and phosphorus losses in a volcanic soil of Southern Chile. J. Soil Sci. Plant Nutr. 8, 200-201.

Alfaro, M., Salazar, F., Oenema, O., Iraira, S., Teuber, N., Ramírez, L., Villarroel, D. 2009. Nutrient balances in beef cattle production systems and their implications for the environment. J. Soil Sci. Plant Nutr. 9, 40-54.

Anrique, R. 1999. Caracterización del Chile lechero. In: Latrille, L. (ed.). Produccion Animal, Universidad Austral de Chile (Chile). pp.140157.

Archer, J.R., Marks, M.J. 1997. Control of nutrient losses to water from agriculture in Europe. The Fertiliser Society Proceedings No. 405.

Betteridge, K., Ledgard, S.F., Lambert, M.G., Thorrold, B., Costall, D.A., Theobald, C.J., Hoogendoorn, C.J., Park, Z.A. 2004. Reduced nitrate leaching from livestock-based system in New Zealand's largest lake catchment. Proceeding of the European Conference for Precision Livestock Farming.

Cameron, K.C., Smith, N.P., McLay, C.D.A., Fraser, P.M., McPherson, R.J., Harrison, D. F., Harbottle, P. 1992. Lysimeter without edge flow: an improved design and sampling procedure. Soil Sci. Soc. Am. J. 56, 1625-1628.
Cameron, K.C., Di, H.J. 2004. Nitrogen leaching losses from different forms and rates of farm effluent applied to a Templeton soil in Canterbury, New Zealand. New Zeal. J. Agr. Res. 47, 429-437.

CIREN, 2003. Descripciones de suelos, materiales y símbolos, estudio agrológico $\mathrm{X}$ Región Vol. II, Centro de Información de Recursos Naturales Santiago Chile.

de Klein, C.A., Ledgard, S.F. 2001. An analysis of environmental and economic implications of nil and restricted grazing systems designated to reduce nitrate leaching from New Zealand dairy farms. I. Nitrogen losses. New Zeal. J. Agr. Res. 44, 201215.

Di, H.J., Cameron, K.C. 2002. Nitrate leaching in temperate agroecosystems: sources, factors and mitigating strategies. Nutr. Cycl. Agroecosys. 46, 237-256.

EC, European Community. 1991. Council directive concerning the protection of water against pollution caused by nitrates from agricultural sources. Official Journal of the European Community (91/676/EEC), Legislation 1375/1-375/8, European Community.

European Environment Agency. 1995. Europe's environment. The Dobříšs Assessment In: Stanners, D. and Bourdeau, P (eds.). Office for Official Publications of the European Communities (Belgium).

Hach. 2000. Procedures Manual Colorimeter DR/890 for total P determination. Hach Company Baltimore USA.

Haynes, R.J, Williams, P.H. 1993. Nutrient cycling and soil fertility in the grazed pasture ecosystem. Adv. Agron. 49, 119-199.

Hawkins, J., Scholefield, D. 2000. Leaching of dissolved organic $\mathrm{N}$ from grass-white clover pasture in SW England. En: Søegaard, K.; Ohlsson, C.; Sehested, J.; Hutchings, N.J. \& Kristensen, T. (eds.). Grassland farming, balancing environmental and economic demands. Proceedings of the 18th General Meeting of the European Grassland Federation. Denmark. Vol 5, Grassland Science in Europe. pp: 378-380.

Hickey, M. B. C., Doran, B. 2004. A review of the efficiency of buffer strips for the maintenance and enhancement of riparian ecosystems. Water Qual. Res. J. Can. 39, 311-317. 
Huygens, D., Rütting, T., Boeckx, P., Van Cleemput, O., Godoy, R., Müller, C. 2007. Soil nitrogen conservation mechanisms in a pristine south Chilean Nothofagus forest ecosystem. Soil Biol. Biochem. 39, 2448-2458.

Huygens, D., Boeckx, P., Templer, P., Paulino, P., Van Cleemput, O., Oyarzun, C., Muller, C., Godoy, R. 2008. Mechanisms for retention of bioavailable nitrogen in volcanic rainforest soils. Nature 1, 543-548

Ignazi, J.C. 1996. Code of best agricultural practices. Fert. Res. 43, 241.

Isermann, K. 1990. Share of agriculture in nitrogen and phosphorus emissions into the surface waters of Western Europe against the background of their eutrophication. Fert. Res. 26, 253-269.

Jarvis, S.C. 2002. Environmental impacts of cattle housing and grazing. In: M. Kaske, H. Scholz, M. Höltershinken (editors). Recent developments and perspectives in bovine medicine. Keynotes lectures of the 22nd World Buiatrics Congress. Germany. pp: 10-23.

Ledgard, S.F., Clark, D.A., Sprosen, M.S., Brier, G.J., Nemaia, E.K.K. 1996. Nitrogen losses from grazed dairy pasture, as affected by nitrogen fertiliser application. Proc. New Zeal. Grass. Assoc. 57, 21-25.

Ledgard, S.F., Penno, J.W., Sprosen, M.S. 1999. Nitrogen inputs and losses from clover/grass pastures grazed by dairy cows, as affected by nitrogen fertilizer application. J. Agri. Sci. (Cambridge) 132, 215-225.

Lord, E.I., Shepherd, M.A. 1993. Development in the use of porous ceramic cups for measuring nitrate leaching. J. Soil Sci. 44, 435-449.

Misselbrook, T.H., Laws, J.A., Pain, B.F. 1996. Surface applications and shallow injection of cattle slurry on grassland: nitrogen losses, herbage yields and nitrogen recoveries. Grass Forage Sci. 51, 270-277.

Mulvaney, C.S. 1996. Nitrogen-inorganic forms. In: Sparks, D. L. (ed.), and J. M. Bartels (Manag. ed.). Methods of soil Analysis: Chemical Methods Part. 3. Soil Sci. Soc. Am., Inc. Am., Soc. Agron. Madison, Wis. USA pp: 1152:1155.

Murphy, D.V., Macdonald, A.J., Stockdale, E.A., Goulding, K.W.T., Fortune, S., Gaunt, J.L., Poulton, P.R., Wakefield, J.A., Webster, C.O., Wilmer, W.S. 2000. Soluble organic nitrogen on agricultural soils. Biol. Fert. Soils 30, 374-387.

Neeteson, J.J. 2000. Nitrogen and phosphorus management on Dutch dairy farms: legislation and strategies employed to met the regulations. Biol. Fert. Soils 30, 566-572.

Nissen, J., Daroch, R., 1991. Efecto del riego sobre la lixiviación de nitrógeno en una pradera de rotación corta para la zona agroclimática de Valdivia. Agro Sur 19, 124129.

Nuñez, R., Demanet, R., Misselbrook, T. Alfaro, M., Mora, M.L. 2010. Nitrogen losses under different cattle grazing strategies in a volcanic soil of Southern Chile. Chil. J. Agr. Res. $70,237-250$

ODEPA. 2006. Boletín de la leche, 1996. ODEPA, Ministerio de Agricultura (Chile).

ODEPA. 2007. Oficina de Estudios y Políticas Agrarias home page, Ministerio de Agricultura (Chile). Available at: http:// www.minagri.gob.cl/webodepa/odepa.html

Powlson, D.S. 2000. Tackling nitrate from agriculture. Soil Use Manage. 16, 141.

Preedy, N., McTiernan, K., Matthews, R., Heathwaite, L. and Haygarth, P.M. 2001. Rapid incidental phosphorus transfers from grassland. J. Environ. Qual. 30: 2105-2112.

Robarge, W.P., Edwards, A., Johnson, B. 1983. Water and waste water analysis for nitrate via nitration of salicylic acid. Commun. Soil Sci. Plan. 14, 1207-1215.

Ryden, J.C., Ball, P.R., Garwood, E.A. 1984. Nitrate leaching from grassland. Nature 311,50 53.

Salazar, M. 2002. Lixiviación de nitrógeno, en el período de mayor crecimiento de una pradera de Lolium multiflorum cv. Tama. Estudio en lisímetros. Tesis de grado para optar al título de Ingeniero Agrónomo de la Universidad de $\mathrm{La}$ Frontera, Temuco, Chile. 110p.

Salazar, F., Alfaro, M., Teuber, N., Iraira, S., Villarroel, D., Ramirez, L. 2005. Pérdidas de nitrógeno por arrastre uperficial y lixiviación en sistemas de producción de carne de la Décima Región. En: Libro de resúmenes de la XXX Reunión Anual de la Sociedad Chilena de Producción Animal. López, I y Sepúlveda, N. (eds.). 19-21 de Octubre, Temuco, Chile. pp: 221-222. 
Effect of the stocking rate and land slope on $N$ losses on southern Chilean pastures, Salazar at al.

Smith, R., Moreira, V., Latrille, L. 2002. Caracterización de sistemas productivos lecheros en la X Región de Chile mediante análisis multivariable. Chil. J. Agr. Res. 62, 375-395.

Webster, C.P., Shepherd, M.A., Goulding, K.W.T., Lord, E. 1993. Comparison of methods for measuring the leaching of mineral nitrogen from arable land. J. Soil Sci. 44, 49-62. 